\title{
Effective Dose Radon 222 of the Tap Water in Children and Adults People; Minab City, Iran
}

\author{
Yadolah Fakhri ${ }^{1}$, Morteza Kargosha ${ }^{1}$, Ghazaleh Langarizadeh ${ }^{2}$, Yahya Zandsalimi ${ }^{3}$, Leila Rasouli Amirhajeloo ${ }^{4}$, \\ Mahboobeh Moradi ${ }^{5}$, Bigard Moradi ${ }^{6} \&$ Maryam Mirzaei $^{7}$ \\ ${ }^{1}$ Social Determinants in Health Promotion Research Center, Hormozgan University of Medical Sciences, Bandar \\ Abbas, Iran \\ ${ }^{2}$ Food and Drugs Research Center, Bam University of Medical Sciences, Bam, Iran \\ ${ }^{3}$ Environmental Health Research Center, Kurdistan University of Medical Sciences, Sanandaj, Iran \\ ${ }^{4}$ Department of Environmental Health Engineering, School of Public Health, Qom University of Medical \\ Sciences, Qom, Iran \\ ${ }^{5}$ Department of Environmental Health Engineering, School of Public Health, Shahid Beheshti University of \\ Medical Sciences, Tehran, Iran \\ ${ }^{6}$ Department of Health Public, Kermanshah University of Medical Sciences, Kermanshah, Iran \\ ${ }^{7}$ Jahrom University of Medical Sciences, Jahrom, Iran \\ Correspondence: Maryam Mirzaei, Research Center for Non-Communicable Disease, Jahrom University of \\ Medical Sciences, Jahrom, Iran. E-mail: Maryammirzaei32@yahoo.com
}

Received: June 19, 2015 Accepted: July 10, 2015 Online Published: August 31, 2015

doi:10.5539/gjhs.v8n4p234 URL: http://dx.doi.org/10.5539/gjhs.v8n4p234

\begin{abstract}
${ }^{222} \mathrm{Rn}$ is a radioactive, odorless, and colorless element which has a half-life of 3.83 days. One of ${ }^{222} \mathrm{Rn}$ main resources are Groundwater (wells, springs, etc.). Hence, the use of groundwater with high concentration of ${ }^{222} \mathrm{Rn}$ can increase the risk of lung and stomach cancers. Concentration of ${ }^{222} \mathrm{Rn}$ in tap water of Minab city in two temperatures 5 and $15^{\circ} \mathrm{C}$ was measured by radon meter model RTM1668-2. The effective dose was calculated by equations proposed by UNSCEAR. Geometric mean concentration of ${ }^{222} \mathrm{Rn}$ in drinking water was found to be $0.78 \pm 0.06$ and $0.46 \pm 0.04 \mathrm{~Bq} / 1$ at 5 and $15{ }^{\circ} \mathrm{C}$ (p value $<0.05$ ), respectively. The effective doses were 0.006 and $0.003 \mathrm{mSv} / \mathrm{y}$ for adults, and 0.011 and $0.007 \mathrm{mSv} / \mathrm{y}$ for the children, respectively ( $\mathrm{p}$ value $<0.05$ ). Besides, the effective dose for adult through inhaling ${ }^{222} \mathrm{Rn}$ at 5 and $15{ }^{\circ} \mathrm{C}$ were estimated 0.0021 and $0.0012 \mathrm{mSv} / \mathrm{y}$, respectively. Geometric mean concentration in ${ }^{222} \mathrm{Rn}$ drinking water and effective dose received from drinking water and inhalation of ${ }^{222} \mathrm{Rn}$ is lower than WHO and EPA standard limits. Increasing temperature of drinking water will decrease the effective dose received. Annual Effective dose received from inhalation and consumption of ${ }^{222} \mathrm{Rn}$ in drinking water in children is more than adults.
\end{abstract}

Keywords: Radon 222, Effective dose, tap water, child and adults humans

\section{Introduction}

Radon $222\left({ }^{222} \mathrm{Rn}\right)$ is produced as a result of decay of Radium $226\left({ }^{226} \mathrm{Ra}\right)$ in Uranium $235\left({ }^{235} \mathrm{U}\right)$ chain. This element is radioactive, odorless, colorless, and water soluble and has a half-life of 3.83 days (Al-Khateeb, Al-Qudah, Alzoubi, Alqadi, \& Aljarrah, 2012; Ju, Ryu, \& Jang, 2012). Several studies indicate that ${ }^{222} \mathrm{Rn}$ indoor air concentration have a significant relationship with lung cancer (Torres-Durán, Barros-Dios, Fernández, \& Ruano-Ravina, 2014). Indoor air death rate from ${ }^{222} \mathrm{Rn}$ has been announced approximately 21,000 people a year, 10 times more than air pollution deaths (Environmental Protection Agency, 2010). Studies have shown that ${ }^{222} \mathrm{Rn}$, received the annual effective dose $1.3 \mathrm{mSv} / \mathrm{y}$ due to natural exposure $(2.4 \mathrm{mSv} / \mathrm{y})$ to dedicate (Over $\left.50 \%\right)$ (Magill \& Galy, 2005). United Nations Scientific Committee on the effects of atomic radiation (UNSCEAR) has expressed exposure standard effective dose received from natural radioactive $2.5 \mathrm{mSv} / \mathrm{y}$, which is $1 \mathrm{mSv} / \mathrm{y}$ related to ${ }^{222} \mathrm{Rn}$ (Mehra and Bala, 2013; Radiation, 2000). ${ }^{222} \mathrm{Rn}$ in drinking water can enter the internal organs such as the stomach and cause cancer (Somlai, Tokonami, Ishikaw, Vancsur, Gáspár, 2007; Auvinen, Salonen, Pekkanen, Pukkala, \& Ilus, 2005; Alizadeh, Mahvi, \& Fakhri, 2014). Also ${ }^{222}$ Rn inhalation can cause damage to 
DNA lung cells and leads to lung cancer in the population (Todorovic, Nikolov, Forkapic, Bikit, \& Mrdja, 2012; Motesaddi, Fakhri, Alizadeh, Mohseni, \& Jafarzadeh, 2014). European Commission and the World Health Organization has proposed concentration of ${ }^{222} \mathrm{Rn}$ in the drinking water, $100 \mathrm{~Bq} / 1$ as the standard limit (WHO, 2006). EPA $11 \mathrm{~Bq} / 1$, has been suggested as the maximum concentration Level (MCL) of ${ }^{222} \mathrm{Rn}$ in drinking water (Environmental Protection Agency, may 2012). Many studies have shown that groundwater resources rather than surface water resources have much higher concentration of radioactive materials such as ${ }^{222} \mathrm{Rn}$ (Amin, 2013; Rožmarić, Rogi, Benedik, \& Štrok, 2012). The total indicative dose (TID) induced by radioactive substances $\left({ }^{3} \mathrm{H}\right.$, ${ }^{40} \mathrm{~K},{ }^{222} \mathrm{Rn}$ ) as well as those produced through ${ }^{222} \mathrm{Rn}$ decayed in drinking water is reported to be $0.1 \mathrm{mSv} / \mathrm{y}$ by WHO and the European committee (Somlai at al., 2007 ; Todorovic at al., 2012 ; WHO, 2004). Due to the exit of ${ }^{222} \mathrm{Rn}$ during water transfer in distribution network, water transfer from one container to another, storing and boiling water, determining the standardized effective dose induced by ${ }^{222} \mathrm{Rn}$ is difficult (Ishikawa, Tokonami, Yoshinaga, \& Narazaki, 2005). Hence, the effective standard level dose $0.1 \mathrm{mSv} / \mathrm{y}$ is used for the analysis. In the present study, the effective dose of ${ }^{222} \mathrm{Rn}$ received by children and adult age groups in Minab drinking water was calculated.

\section{Materials and Methods}

\subsection{Study Area}

Minab city with a population of approximately 90 thousand people is located in geographic coordinates $27^{\circ} 06^{\prime} 40 \mathrm{~N}$ and $57^{\circ} 05^{\prime} 52$, at an elevation of 45 meters above sea level (Figure 1). The city is located in a hot and humid region and the water consumption per capital was high. The only water resources in this town are three deep wells (Groundwater source), the water of which is pumped out and distributed with no purification process.

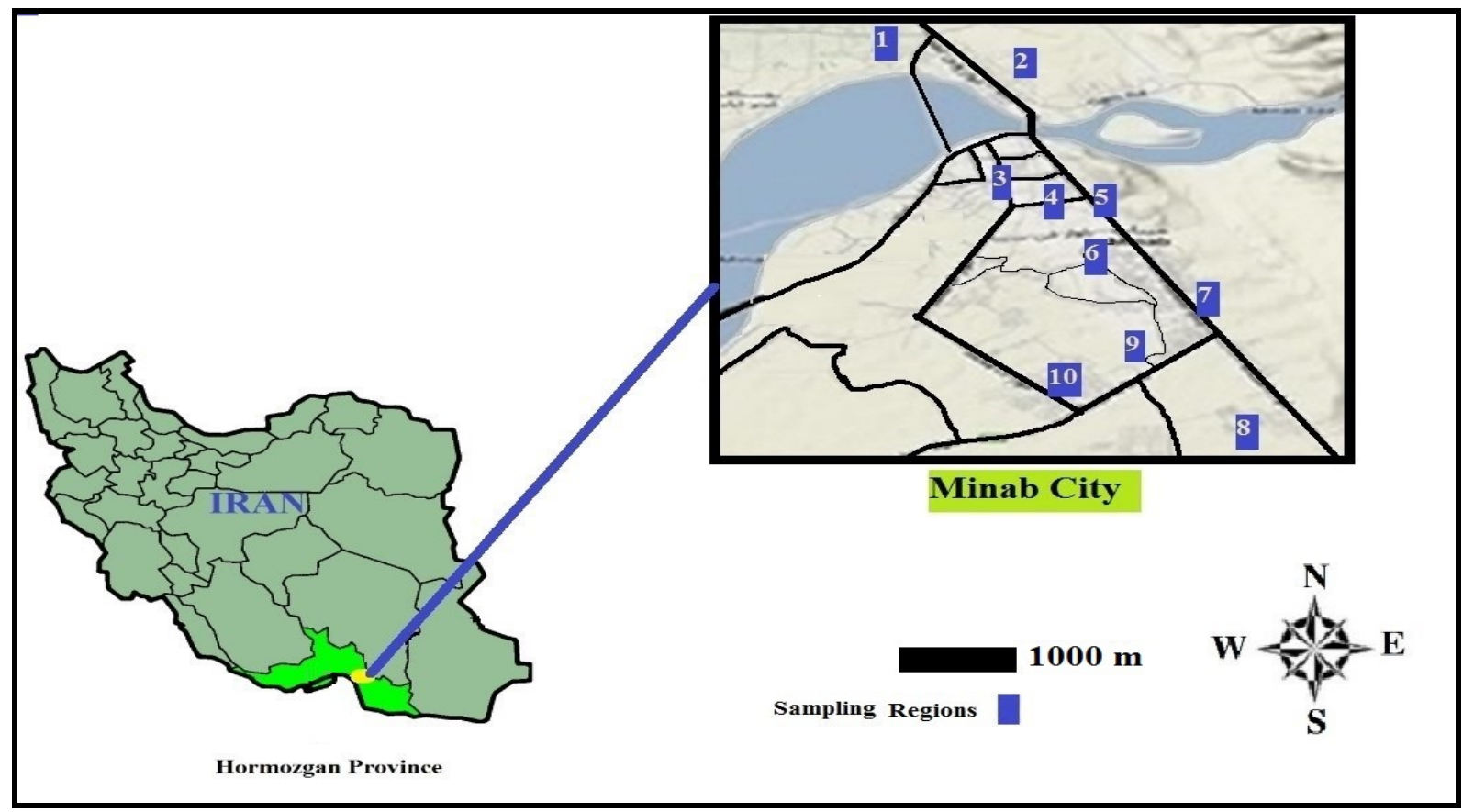

Figure 1. sampling regions of Minab in the East province of Hormozgan, Iran (2)

\subsection{Sample Collection}

Since the retention time of water in the distribution network is effective on the concentration of ${ }^{222} \mathrm{Rn}$ (Ishikawa, Tokonami, Yoshinaga, \& Narazaki, 2005), thus, the sampled locations were determined from the beginning to the end of the distribution network. For 4 consecutive months, the sampling was done in 10 regions of the town. Meanwhile, 25 samples were selected from each region. During each stage of time, a total of 250 samples, each containing 21 of city tap water were obtained from 10 regions Sampling was conducted according to the proposed method (EPA).

\subsection{Measurement Concentration of ${ }^{222} R n$}

Measurement of radioactive substances in water, soil and air are done in various ways, such as alpha 
spectrophotometry, inductively coupled plasma/mass spectrophotometer, gamma spectrophotometry and liquid Scintillation (Rožmarić, Rogi, Benedik, \& Štrok, 2012). Recently, many studies measure the concentration of ${ }^{222} \mathrm{Rn}$ portable devices, such as RAD7 RTM (Mehra and Bala, 2013; Ju, Ryu, Jang, Dong, \& Chung, 2012; Todorovic, Jovana Nikolov, Sofija Forkapic, Istvan Bikit, \& Dusan Mrdja, 2012; Lee \& Kim, 2006). Hence, in this study a model of portable alpha spectrophotometry RTM1688-2 was used to measure ${ }^{222} \mathrm{Rn}$ in drinking water. To determine the effect of water temperature on the diffusion rate ${ }^{222} \mathrm{Rn}$ of water, measurements was done at 5 and $15^{\circ} \mathrm{C}$ temperatures. According to measurement of $300 \mathrm{~mL}$, after the sample size reached the intended temperature, the device was placed in a closed cycle (Figure 2). The time for balance between concentration of ${ }^{222} \mathrm{Rn}$ and its decay products (daughters ${ }^{222} \mathrm{Rn}$ ) is 4 hour approximately (Ju, Ryu, \& Jang, 2012; Mehra \& Bala, 2013; Lee \& Kim, 2006). Hence, the 4 hour mean concentration of ${ }^{222} \mathrm{Rn}(\mathrm{Bq} / \mathrm{l})$ and the initial temperature $\left({ }^{\circ} \mathrm{C}\right)$ was recorded.

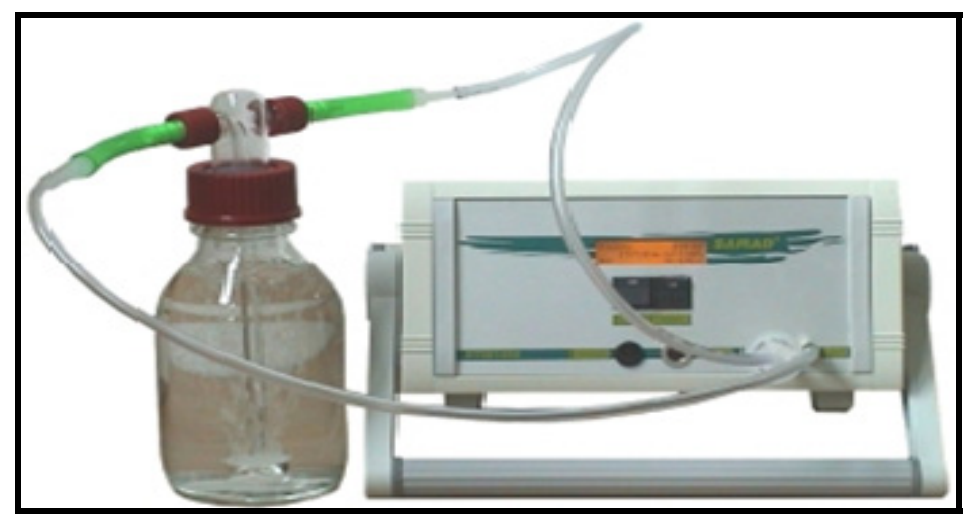

Figure. 2. Measurement water ${ }^{222} \mathrm{Rn}$ levels by RTM 1688-2 device, manufactured by Sarad corporation in Germany.

\subsection{Calculation of effective dose (Ingestion)}

To determine ${ }^{222} \mathrm{Rn}$ annual effective dose received in the stomach from water consumption, Equation 1 was used (Sarad, 2009). In this equation $\mathrm{E}$ : the annual effective dose received by $\mathrm{mSv} / \mathrm{y}$, K: Coefficient conversion concentration of ${ }^{222} \mathrm{Rn}$ to effective dose According to $\mathrm{mSv} / \mathrm{Bq}, \mathrm{KM}$ : Annual water consumed 1/y, C: the concentration of ${ }^{222} \mathrm{Rn}$ depending on $\mathrm{Bq} / \mathrm{l}$ and $\mathrm{T}$ : the period of water consumption in the study, here was 365 days (Somlai, Tokonami, Ishikawa, Vancsura, \& Gáspár, 2007).

$$
\mathrm{E}=\mathrm{K} \times \mathrm{C} \times \mathrm{KM} \times \mathrm{T}
$$

Conversion factor for adults and children were $1 \times 10^{-8} \mathrm{~Sv} / \mathrm{Bq}$ and $2 \times 10^{-8} \mathrm{~Sv} / \mathrm{Bq}$, respectively (Amin, 2013; WHO, 2004). KM is daily consumption which is considered $2 \mathrm{l} / \mathrm{d}$.

\subsection{Calculation of the Effective Dose (Inhalation)}

In order to estimate the effective dose received annually through inhaling ${ }^{222} \mathrm{Rn}$ of underground water, the conversion coefficient of $2.8 \mu \mathrm{Sv}$.lit/Bq was used (Radiation, 2000). The annual geometric mean concentration of ${ }^{222} \mathrm{Rn}(\mathrm{Bq} / \mathrm{l})$ was multiplied by the coefficient $2.8 \times 10^{-3}$, and the effective dose received annually through inhaling ${ }^{222} \mathrm{Rn}$ was estimated in $\mathrm{mSv} / \mathrm{y}$.

\subsection{Statistical Analyses}

Statistical analyses were done via SPSS 16, using One-way ANOVA method and correlation coefficient. The results were also stated in mean and standard deviation forms.

\section{Results}

Geometric mean and range of concentration of ${ }^{222} \mathrm{Rn}$ in drinking water was measured $0.78 \pm 0.06 \mathrm{~Bq} / 1$ and 0.19-1.7 Bq/1 at $5{ }^{\circ} \mathrm{C}$ and $0.46 \pm 0.04 \mathrm{~Bq} / 1$ and $0.16-1.45 \mathrm{~Bq} / 1$ at $15^{\circ} \mathrm{C}$, respectively (p value $<0.05$ ). (Tables 1 and 2). 
Table 1. Geometric mean $(\mathrm{GM} \pm \mathrm{SE})$, Middle, maximum and minimum concentration of ${ }^{222} \mathrm{Rn}$ tap water samples in the temperature of $5{ }^{\circ} \mathrm{C}(\mathrm{Bq} / \mathrm{l})(\mathrm{n}=250$; Note 1$)$

\begin{tabular}{lllll}
\hline Regions & Minimum & Maximum & Middle & Geometric mean \\
\hline 1 & 0.96 & 1.8 & 0.24 & $1.17 \pm 0.1$ \\
2 & 0.77 & 1.71 & 0.5 & $1.14 \pm 0.1$ \\
3 & 0.68 & 1.08 & 0.98 & $0.93 \pm 0.08$ \\
4 & 0.78 & 1.15 & 0.9 & $0.92 \pm 0.08$ \\
5 & 0.48 & 0.96 & 0.87 & $0.77 \pm 0.06$ \\
6 & 0.65 & 0.89 & 0.76 & $0.72 \pm 0.06$ \\
7 & 0.42 & 0.69 & 0.56 & $0.57 \pm 0.5$ \\
8 & 0.43 & 0.85 & 0.72 & $0.65 \pm 0.5$ \\
9 & 0.26 & 0.65 & 0.46 & $0.47 \pm 0.4$ \\
10 & 0.2 & 0.65 & 0.54 & $0.49 \pm 0.4$ \\
\hline
\end{tabular}

Table 2. Geometric mean $(\mathrm{GM} \pm \mathrm{SE})$, Middle, maximum and minimum concentration of ${ }^{222} \mathrm{Rn}$ drinking water samples in the temperature of $15^{\circ} \mathrm{C}(\mathrm{Bq} / \mathrm{l})(\mathrm{n}=250)$

\begin{tabular}{lllll}
\hline Regions & Min & Max & Middle & Geometric mean \\
\hline 1 & 0.6 & 1.14 & 0.78 & $0.81 \pm 0.6$ \\
2 & 0.54 & 1.45 & 0.76 & $0.86 \pm 0.7$ \\
3 & 0.26 & 0.82 & 0.59 & $0.53 \pm 0.4$ \\
4 & 0.48 & 0.88 & 0.62 & $0.62 \pm 0.5$ \\
5 & 0.17 & 0.75 & 0.53 & $0.48 \pm 0.4$ \\
6 & 0.19 & 0.75 & 0.47 & $0.43 \pm 0.3$ \\
7 & 0.18 & 0.49 & 0.32 & $0.33 \pm 0.2$ \\
8 & 0.16 & 0.49 & 0.39 & $0.37 \pm 0.3$ \\
9 & 0.17 & 0.54 & 0.29 & $0.27 \pm 0.2$ \\
10 & 0.2 & 0.42 & 0.26 & $0.27 \pm 0.2$ \\
\hline
\end{tabular}

The percent of concentration frequency distributions of ${ }^{222} \mathrm{Rn}$ in drinking water of 10 regions of Minab city in temperatures 5 and $15{ }^{\circ} \mathrm{C}$ are shown in Figures 3 and 4. The maximum and minimum frequency distribution concentration of ${ }^{222} \mathrm{Rn}$ at the temperature of $5{ }^{\circ} \mathrm{C}$ was observed in the range of $0.6-0.9 \mathrm{~Bq} / 1$ and $>0.4 \mathrm{~Bq} / \mathrm{l}$, respectively. At the temperature of $15^{\circ} \mathrm{C}$, they were observed in the range of $>0.4 \mathrm{~Bq} / 1$ and $1.1-1.3 \mathrm{~Bq} / 1$. 


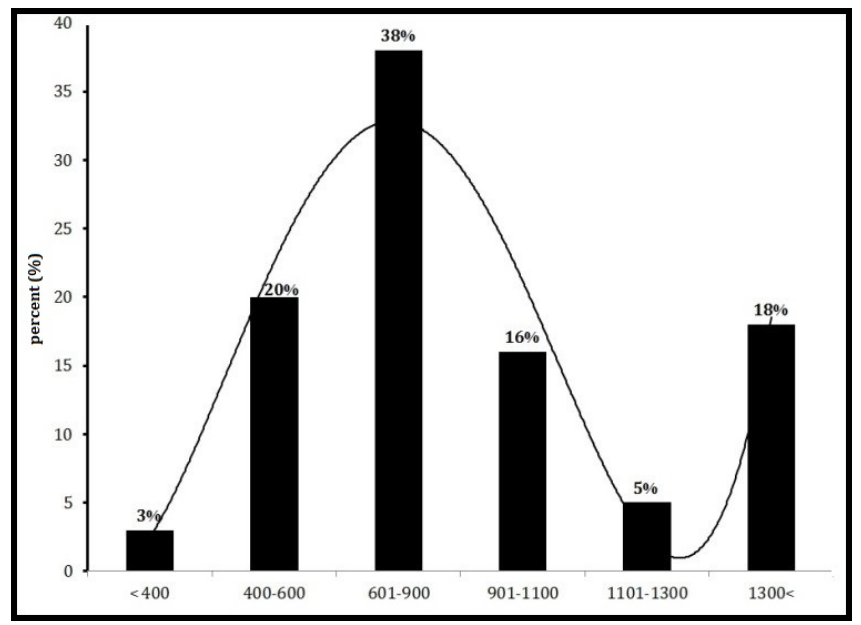

Figurer 3. Percent of frequency distributions concentration of ${ }^{222} \mathrm{Rn}$ Drinking water temperature in $5{ }^{\circ} \mathrm{C}$

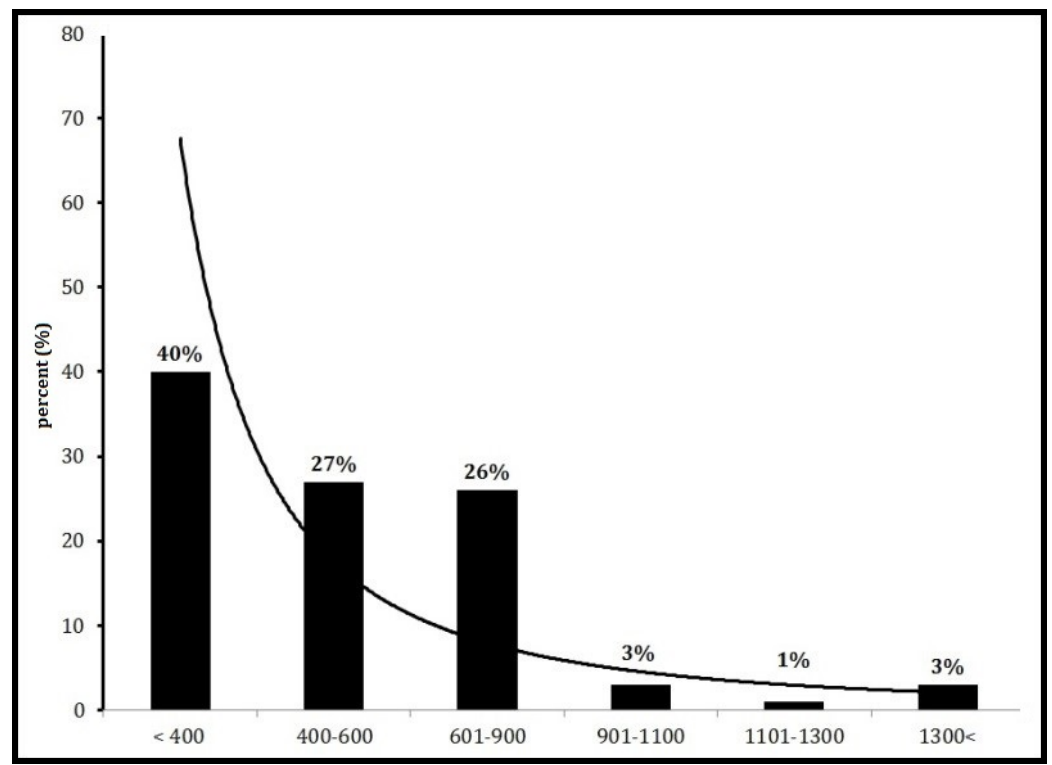

Figure 4. Percent of frequency distribution concentration of ${ }^{222} \mathrm{Rn}$ in drinking water at $15^{\circ} \mathrm{C}$

The effective dose received annually through drinking water at the temperature of $5{ }^{\circ} \mathrm{C}$ in the children and adult groups was 0.011 and $0.007 \mathrm{mSv} / \mathrm{y}$, respectively. At the temperature of $15^{\circ} \mathrm{C}$ it was 0.007 and $0.003 \mathrm{mSv} / \mathrm{y}(\mathrm{p}$ value $<0.05$ ). The effective dose received annually through inhaling ${ }^{222} \mathrm{Rn}$ in drinking water at the temperatures of $5^{\circ} \mathrm{C}$ and $15{ }^{\circ} \mathrm{C}$ were 0.0021 and $0.0012 \mathrm{mSv} / \mathrm{y}$, respectively ( $\mathrm{p}$ value $<0.05$ ). 


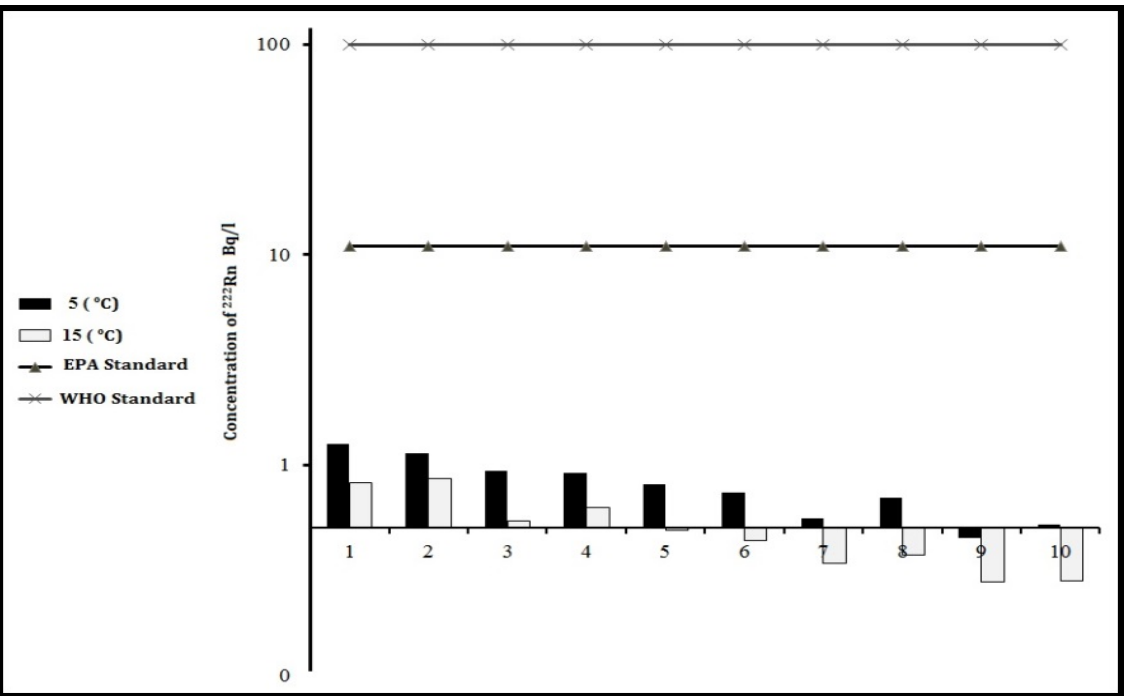

Figure 5. Geometric mean concentration of ${ }^{222} \mathrm{Rn}$ drinking water in 10 regions of Minab at the temperatures of $5{ }^{\circ} \mathrm{C}$ and $15{ }^{\circ} \mathrm{C}$

\section{Discussion}

Geometric mean concentration of ${ }^{222} \mathrm{Rn}$ of drinking water at $5{ }^{\circ} \mathrm{C}(0.78 \pm 0.06 \mathrm{~Bq} / \mathrm{l})$ is greater than of $15{ }^{\circ} \mathrm{C}$ $(0.46 \pm 0.04 \mathrm{~Bq} / \mathrm{l})$. $\mathrm{P}$ value $<0.05$ between concentration of ${ }^{222} \mathrm{Rn}$ of drinking water in temperatures 5 and $15^{\circ} \mathrm{C}$, indicate a significant difference. Consistent with our results, several studies reduce emissions ${ }^{222} \mathrm{Rn}$ where the effect of reduced water solubility was observed as the temperature increased (Yalcin, Gurler, Akar, Incirci, \& Kaynak, 2011; GalipYucea \& Gasparonb, 2013; Oner, Yalim, Akkurt, \& Orbay, 2009).

Table 3. Range concentration of ${ }^{222} \mathrm{Rn}$ in tap water of Minab city compared with some other cities

\begin{tabular}{llll}
\hline Country / City & Water source & Range & References \\
\hline Pakistan/Islamabad & Groundwater & $25.9-158.4$ & (Ali, Khan, Akhter, Khan and Waheed, 2010) \\
Italy/Umberia & Groundwater & $5.9-65.7$ & (Borio, Rongoni, Saetta, Desideri and Roselli, 2005) \\
Turkey/Amasiya & Groundwater & $0.39-1.17$ & (Oner, Yalim, Akkurt and Orbay, 2009) \\
China/Bovaji & Groundwater & $12-41$ & (Xinwei, 2006) \\
Iran/Tehran & Groundwater & $27.7-74.3$ & (N.Alirezazadeh, 2005) \\
Iran/Minab & Groundwater & $0.16-1.7$ & This Study \\
\hline
\end{tabular}

As it can be seen in Table 3, the range concentration of ${ }^{222} \mathrm{Rn}$ in drinking water of Amasiya $(0.39-1.17 \mathrm{~Bq} / \mathrm{l})$ is within the range concentration of ${ }^{222} \mathrm{Rn}$ drinking water of Minab $(0.16-1.7 \mathrm{~Bq} / 1)$. The range concentration of ${ }^{222} \mathrm{Rn}$ in drinking water of Tehran (27.7-74.3 Bq/l), Buvaji $(12-41 \mathrm{~Bq} / \mathrm{l})$, Uberiya $(5.9-65.7 \mathrm{~Bq} / \mathrm{l})$, and Islamabad (25.9-158.4 Bq/l) are much greater than Minab and Amasiya cities. Difference concentration of ${ }^{222} \mathrm{Rn}$ in these towns (Amasiyia and Minab) may be due to different factors such as concentration of ${ }^{222} \mathrm{Rn}$ in the water source, geological substrate type, water retention time and temperature during the measurement (Yiğitoğlu, Öner, Yalim, Akkurt, Okur, 2010). Groundwater resources (springs, wells, etc.) due to contact with the various layers of the earth, has more Total Dissolved Solid (TDS), including radioactive materials relative to surface waters (rivers, lakes, etc.). Layers of earth containing igneous rocks (granite) are larger, with higher concentration of radioactive material ${ }^{235} \mathrm{U}$ (Rožmarić, Rogi, Benedik, \& Štrok, 2012; Rezaei \& Jalili-Majareshin, 2011). Since the ${ }^{222} \mathrm{Rn}$ is the product of series of ${ }^{235} \mathrm{U}$ decay, it can be expected that concentration in groundwater which cross from substrate type, are higher (Przylibski, Mamont-Cies'la, Kusyk, Dorda, \& Kozlowska, 2004). Drinking water sources in Tehran, Buage, Umbria and Islamabad are of underground type similar to Minab and Amasia. However, concentration of $222 \mathrm{Rn}$ in the drinking water of Minab and Amasia is different. This could be due to differences in geological structure, measuring temperature and retention time of water. The effective dose received by 
children age group at the temperature of $5{ }^{\circ} \mathrm{C}(0.011 \mathrm{mSv} / \mathrm{y})$ was 1.57 times more than of that at $15^{\circ} \mathrm{C}(0.006$ $\mathrm{mSv} / \mathrm{y})$. For adults it was 2 times bigger. Since the mean concentration of ${ }^{222} \mathrm{Rn}$ at $5{ }^{\circ} \mathrm{C}(0.78 \pm .06 \mathrm{~Bq} / \mathrm{l})$ is more than that of $15^{\circ} \mathrm{C}\left(0.46 \pm .04 \mathrm{Bql}^{-1}\right)$, the effective dose received is higher at this temperature. The effective dose received annually by adults and children from drinking water at 5 and $15^{\circ} \mathrm{C}$ was below the standard $0.1 \mathrm{mSv} / \mathrm{y}$. The activated coefficient of converting ${ }^{222} \mathrm{Rn}$ to effective dose is higher in children group than adults (Somlai at al., 2007). The effective dose received from drinking water in this age group at the temperatures of 5 and $15{ }^{\circ} \mathrm{C}$ are 1.83 and 2.33 times bigger than adults'.

Table 4. Annual effective dose received by age groups of children and adults caused by the inhalation ${ }^{222} \mathrm{Rn}$ and ingestion of tap water Minab (Iran) and other cities

\begin{tabular}{|c|c|c|c|c|}
\hline \multirow{3}{*}{ City / Country } & \multicolumn{4}{|c|}{ Annual effective dose } \\
\hline & \multicolumn{2}{|c|}{ Drinking water (stomach) $\mathrm{mSv} / \mathrm{y}$} & \multirow{2}{*}{$\begin{array}{l}\text { Inhalation (lung) } \\
\mathrm{mSv} / \mathrm{y}\end{array}$} & \multirow[t]{2}{*}{ References } \\
\hline & Childs & adults & & \\
\hline Minab/Iran ${ }^{1}$ & 0.011 & 0.006 & 0.0021 & This study \\
\hline Minab/Iran ${ }^{2}$ & 0.007 & 0.003 & 0.0012 & This study \\
\hline Mashhad/Iran & - & 0.00029 & 0.0004 & $\begin{array}{l}\text { (Binesh, Mohammadi, Mowlavi, \& } \\
\text { Parvaresh, 2010) }\end{array}$ \\
\hline Tehran/Iran & 0.000129 & 0.00066 & 0.01 & (N. Alirezazadeh, 2005) \\
\hline Bovaji/China & & & $0.03-0.14$ & (Xinwei, 2006) \\
\hline Balaton/Netherlands & 0.0004 & 0.0002 & & (Somlai at al., 2007) \\
\hline Australia & & 0.005 & & (Kralik, Friedrich and Vojir, 2003) \\
\hline Gotaya/Turkey & - & $0.000122-0.0003$ & $0.00014-0.00003$ & $\begin{array}{l}\text { (Sahin, Çetinkaya, Saç, \& Içhedef, } \\
\text { 2013) }\end{array}$ \\
\hline \multirow[t]{2}{*}{ Kastomono/ Turkey } & - & $0.00032-0.00093^{3}$ & - & (Yalcin at al., 2011) \\
\hline & & $0.00049-0.0008^{4}$ & & \\
\hline
\end{tabular}

Effective dose due to inhalation of ${ }^{222} \mathrm{Rn}$ from drinking water is much lower than the standard $1 \mathrm{mSv} / \mathrm{y}$ effective dose due to ${ }^{222} \mathrm{Rn}$ inhalation (Villalba, Sujoa, Cabrera, Jime'neza, \& Villalobos, 2005). Effective dose received from ${ }^{222} \mathrm{Rn}$ inhalation from drinking water at $5{ }^{\circ} \mathrm{C}$, is 1.82 times bigger than that of temperature $15{ }^{\circ} \mathrm{C}$. As can be seen in Table 4, the effective dose received by children $(0.011$ and $0.007 \mathrm{mSv} / \mathrm{y})$ and adults $(0.006$ and 0.003 $\mathrm{mSv} / \mathrm{y})$ at a temperature 5 and $15{ }^{\circ} \mathrm{C}$ of drinking water of Minab city is greater than Tehran $(0.000129$ and $0.00066 \mathrm{mSv} / \mathrm{y})$, Balaton $(0.0004$ and $0.0002 \mathrm{mSv} / \mathrm{y})$, Mashhad $(0.00029 \mathrm{mSv} / \mathrm{y}$ for adult $)$, Australia $(0.005$ $\mathrm{mSv} / \mathrm{y}$ for adult), Gotaya $(0.000122-0.0003 \mathrm{mSv} / \mathrm{y})$ and Kastomono $(0.00032-0.00093 \mathrm{mSv} / \mathrm{y}$ in summer and $0.00049-0.0008 \mathrm{mSv} / \mathrm{y}$ in the spring). ${ }^{222} \mathrm{Rn}$ concentration range in drinking water of Tehran $(27.7-74.3 \mathrm{~Bq} / \mathrm{l})$ is more than Minab City $(0.16-1.7 \mathrm{~Bq} / \mathrm{l})$. However, due to the low effective dose conversion factor activity $\left(0.35 \times 10^{-8} \mathrm{~Sv} / \mathrm{Bq}\right)$ and capital annual consumption of water (children 75lit and adults 100lit), a lower effective dose is received by people of Tehran (N. Alirezazadeh, 2005). Lower effective dose in other cities can be due to low concentration of ${ }^{222} \mathrm{Rn}$, conversion factors and capital water consumption. Effective dose of induced inhalation in Minab (0.0021 and $0.0012 \mathrm{mSv} / \mathrm{y})$ is higher than cities of Mashhad $(0.0004 \mathrm{mSv} / \mathrm{y})$, Gotiya $(0.00003-0.00014 \mathrm{mSv} / \mathrm{y})$ and is lower than cities of Tehran $(0.01 \mathrm{mSv} / \mathrm{y})$, and Bovaji $(0.03-0.14 \mathrm{mSv} / \mathrm{y})$. However, effective dose of inhalation activity conversion factor of Minab $(2.8 \mu \mathrm{Sv} / \mathrm{y})$ is higher than Tehran cities and Bovaji $\left(1.8 \mu \mathrm{Svy}^{-1}\right.$ ) (Xinwei, 2006; N. Alirezazadeh, 2005), but due to the higher concentration of ${ }^{222} \mathrm{Rn}$ in tap water, inhalation effective dose is higher in Minab city.

\section{Conclusion}

Geometric mean concentration of ${ }^{222} \mathrm{Rn}$ in drinking water at temperatures 5 and $15^{\circ} \mathrm{C}(0.78 \pm 0.06$ and $0.46 \pm 0.04$ 
$\mathrm{Bq} / \mathrm{l}$ ) are lower than EPA and WHO standard limits. Annual Effective dose received from inhalation and consumption of ${ }^{222} \mathrm{Rn}$ in drinking water in children is more than adults ( $p$ value $<0.05$ ). Also, effective dose received in both age groups, are much lower than EPA and WHO standard limits. Increasing the temperature reduces the effect on concentration of ${ }^{222} \mathrm{Rn}$ in drinking water, followed by a reduction in received effective dose. Hence, it is recommended to reduce the effective dose received in the cities with high concentration of ${ }^{222} \mathrm{Rn}$ in drinking water, water ingestion be at higher temperature.

\section{Acknowledgments}

The authors of this paper wish to express their gratitude to the chemical lab staff of Minab urban water and water-waste Company who dedicatedly cooperated in conduction of this research.

\section{Conflict of Interest}

The authors declare that there is no conflict of interests regarding the publication of this paper.

\section{References}

Ali, N., Khan, E., Akhter, P., Khan, F., \& Waheed, A. (2010).Estimation of mean annual effective dose through radon concentration in the water and indoor air of Islamabad and Murree. Radiation Protection Dosimetry, 141, 183-191. http://dx.doi.org/10.1093/rpd/ncq160

Alirezazadeh, N. (2005). Radon concentrations in public water supplies in Tehran and evaluation of radiation dose. Iran. J. Radiat. Res, 3(2), 79-83.

Alizadeh, A., Mahvi, A. H., \& Fakhri, Y. (2014). The Effect of Tobacco Smoking On Concentration of $222 \mathrm{Rn}$ Indoor Air and the Annually Received Effective Dose. Journal of Applied Sciences Research, 10.

Al-Khateeb, H. M., Al-Qudah, A. A., Alzoubi, F. Y., Alqadi, M. K., \& Aljarrah, K. M. (2012). Radon concentration and radon effective dose rate in dwellings of some villages in the district of Ajloun, Jordan. Applied Radiation and Isotopes, 70, 1579-1582. http://dx.doi.org/10.1016/j.apradiso.2012.04.009

Amin, R. M. (2013).Evaluation of radon gas concentration in the drinking water and dwellings of south-west Libya, using CR-39 detectors. International Journal of Environmental Sciences, 4. http://dx.doi.org/10.6088/ijes.2014040400005

Auvinen, A., Salonen, L., Pekkanen, J., Pukkala, E., Ilus, T., \& Kurttio, P. (2005). Radon and other natural radionuclides in drinking water and risk of stomach cancer: A case - cohort study in Finland. International Journal of Cancer, 114, 109-113. http://dx.doi.org/10.1002/ijc.20680

Binesh, A., Mohammadi, S., Mowlavi, A. A., \& Parvaresh, P. (2010). Evaluation of the radiation dose from radon ingestion and inhalation in drinking water. International Journal of Water Resources and Environmental Engineering, 2, 174-178.

Borio, R., Rongoni, A., Saetta, D. M. S., Desideri, D., \& Roselli, C. (2005). Radon and tritium measurements in drinking water in a region of central Italy (Umbria). Journal of Radioanalytical and Nuclear Chemistry, 266, 397-403. http://dx.doi.org/10.1007/s10967-005-0923-2

Galip, Y., \& Gasparonb, M. (2013). Preliminary risk assessment of radon in groundwater: a case study from Eskisehir, Turkey. Isotopes in environmental and health studies, 49(2), 163-179. http://dx.doi.org/10.1080/10256016.2013.739562

Ishikawa, T., Tokonami, S., Yoshinaga, S., \& Narazaki, Y. (2005). Airborne and waterborne radon concentrations in areas with use of groundwater supplies. Journal of radioanalytical and nuclear chemistry, 267, 85-88. http://dx.doi.org/10.1007/s10967-006-0012-1

Ju, Y.-J., Ryu, Y.-H., \& Jang, H.-C. (2012). A Study on Concentration Measurements of Radon-222 (Uranium Series) and Radon-220 (Thoron Series) Emitted to the Atmosphere from Tex (Cementitious), Red Brick, and Ecocarat among Construction Materials. Korean Physical Society, 60, 1177-1186. http://dx.doi.org/10.3938/jkps.60.1177

Ju, Y.-J., Ryu, Y.-H., Jang, H.-C., Dong, K.-R., Chung, W.-K., Cho, J.-H., ... Lim, C.-S. P.-S. (2012). A Study on Concentration Measurements of Radon-222 (Uranium Series) and Radon-220 (Thoron Series) Emitted to the Atmosphere from Tex (Cementitious), Red Brick, and Ecocarat among Construction Materials. Korean Physical Society, 60, 1177-1186. http://dx.doi.org/10.3938/jkps.60.1177

Kralik, C., Friedrich, M., \& Vojir, F. (2003). Natural radionuclides in bottled water in Austria. Journal of environmental radioactivity, 65, 233-241. http://dx.doi.org/10.1016/S0265-931X(02)00099-1 
Lee, J.-M., \& Kim, G. (2006). A simple and rapid method for analyzing radon in coastal and ground waters using a radon-in-air monitor. Journal of Environmental Radioactivity, 89, 219-228. http://dx.doi.org/10.1016/j.jenvrad.2006.05.006

Mehra, R., \& Bala, P. (2013). Estimation of annual effective dose due to Radon level in indoor air and soil gas in Hamirpur district of Himachal Pradesh. Journal of Geochemical Exploration.

Motesaddi, S., Fakhri, Y., Alizadeh, A., Mohseni, S. M., Jafarzadeh, S., \& Mahvi, A. H. (2014). Effective dose of Radon222 and thoron220 in the indoor air of Genow hot springs of Bandar Abbas. Advances in Environmental Biology, 8, 453-459.

Oner, F., Yalim, H., Akkurt, A., \& Orbay, M. (2009). The measurements of radon concentrations in drinking water and the Yeşilırmak River water in the area of Amasya in Turkey. Radiation Protection Dosimetry, 133, 223-226. http://dx.doi.org/10.1093/rpd/ncp049

Przylibski, T. A., Mamont-Cies'la, K., Kusyk, M., Dorda, J., \& Kozlowska, B. (2004). Radon concentrationsin groundwaters of the Polish part of the Sudety Mountains (SW Poland). Journal of Environmental Radioactivity, 75, 193-209.

Radiation, U. N. S. C. o. t. E. o. A. (2000). UNSCEAR 2000. Sources and effects of ionizing radiation, 2.

Rezaei, D., \& Jalili-Majareshin, A. (2011). Concentration rate measurement of radon gas in hot springs of Sarein as a tourism city with RAD7 and investigation physical methods to reduce radon concentration in water. Department of Physics, University of Mohagheghe Ardabili.

Rožmarić, M., Rogi, M., Benedik, L. and Štrok, M. (2012). Natural radionuclides in bottled drinking waters produced in Croatia and their contribution to radiation dose. Science of the Total Environment, 437, 53-60. http://dx.doi.org/10.1016/j.scitotenv.2012.07.018

Sahin, L., Çetinkaya, H., Saç, M. M., \& Içhedef, M. (2013). Determination of radon and radium concentrations in drinking water samples around the city of Kutahya. Radiation Protection Dosimetry, 155, 474-482. http://dx.doi.org/10.1093/rpd/nct019

Somlai, K., Tokonami, S., Ishikaw, T., Vancsur, P., Gáspár, M., Jobbágy, V., Somlai, J., \& Kovács, T. (2007). 222Rn concentrations of water in the Balaton Highland and in the southern part of Hungary, and the assessment of the resulting dose. Radiation Measurements, 42, 491-495

Somlai, K., Tokonami, S., Ishikawa, T., Vancsura, P., Gáspár, M., Jobbágy, V., ... Kovács, T. (2007). 222Rn concentrations of water in the Balaton Highland and in the southern part of Hungary, and the assessment of the resulting dose. Radiation Measurements, 42, 491-495. http://dx.doi.org/10.1016/j.radmeas.2006.11.005

Todorovic, N., JovanaNikolov, SofijaForkapic, IstvanBikit, DusanMrdja, MiodragKrmar and Veskovic, M. (2012).Public exposure to radon in drinking water in SERBIA. Applied RadiationandIsotopes, 70, 543-549. http://dx.doi.org/10.1016/j.apradiso.2011.11.045

Todorovic, N., Nikolov, J., Forkapic, S., Bikit, I., Mrdja, D., Krmar, M., \& Veskovic, M. (2012). Public exposure to radon in drinking water in SERBIA. Applied Radiation and Isotopes, 70, 543-549.

Torres-Durán, M., Barros-Dios, J. M., Fernández-, A., \& Ruano-Ravina, V. A. (2014). Residential radon and lung cancer in never smokers: A systematic review. Cancer Letters.

Villalba, L., Sujoa, L. C., Cabrera, M. E. M., Jime'neza, A. C., Villalobos, M. R. a., Mendoza, C. J. D., Tenorio, L. A. J., Rangeld, I. D. v., \& Peraz, E. F. H. (2005). Radon concentrations in ground and drinking water in the state of Chihuahua, Mexico. Journal of Environmental Radioactivity, 80, 139-151. http://dx.doi.org/10.1016/j.jenvrad.2004.08.005

WHO. (2004). Guidelines for drinking-water quality: Recommendations. World Health Organization, 1.

WHO. (2006). Guidelines for drinking-water quality: First addendum to volume 1, Recommendations. World Health Organization, 1.

Xinwei, L. (2006).Analysis of radon concentration in drinking water in Baoji (China) and the associated health effects. Radiation Protection Dosimetry, 121, 452-455. http://dx.doi.org/10.1093/rpd/ncl048

Yalcin, S., Gurler, O., Akar, U. T., Incirci, F., Kaynak, G., \& Gundogdu, O. (2011).Measurements of radon concentration in drinking water samples from Kastamonu (Turkey). Isotopes in environmental and health studies, 47, 438-445. http://dx.doi.org/10.1080/10256016.2011.618270 
Yiğitoğlu, I., Öner, F., Yalim, H., Akkurt, A., Okur, A., \& Özkan, A. (2010). Radon concentrations in water in the region of Tokat city in Turkey. Radiation Protection Dosimetry, 142, 358-362. http://dx.doi.org/10.1093/rpd/ncq191

\section{Copyrights}

Copyright for this article is retained by the author(s), with first publication rights granted to the journal.

This is an open-access article distributed under the terms and conditions of the Creative Commons Attribution license (http://creativecommons.org/licenses/by/3.0/). 